Victoria E. McArthur • Drosos Koutsoubas

Nikolaos Lampadariou • Costas Dounas

\title{
The meiofaunal community structure of a Mediterranean lagoon (Gialova lagoon, Ionian Sea)
}

Received: 2 March 1999 / Received in revised form: 6 December 1999 / Accepted: 9 December 1999

\begin{abstract}
The higher taxonomic structure of a meiofaunal community was investigated in an Eastern Mediterranean lagoon (Gialova lagoon, Ionian Sea). Seven stations were sampled on a seasonal basis during 1995-1996. Stations within the lagoon were found to support a maximum of 14 meiofaunal taxa with densities ranging from 17 to over 2000 individuals per $10 \mathrm{~cm}^{2}$. Nematodes were not always the most abundant taxa, although they dominated about half of the total 28 samples. Uni- and multivariate analyses were employed to study the community structure. The distribution pattern of the meiofaunal community varied both across the lagoon and over the seasons. On the basis of the spatial differences a meiofaunal coenocline, correlated with the degree of isolation, was observed, composed of mainly two zones: one defined by the area close to the marine channel and the other the more isolated area in the inner lagoon. Meiofaunal distribution pattern was not clearly correlated to one environmental variable, but rather to many, and spatial and seasonal effects could be seen.
\end{abstract}

Key words Meiobenthos - Coastal lagoons · Population structure and dynamics · Ionian Sea $\cdot$ Eastern

Mediterranean

\section{Introduction}

Lagoons are typically shallow, soft-bottomed habitats which are characterised by often rapid and unpredictable fluctuations in environmental parameters on a seasonal or even daily basis, which cause changes in the structure and distribution pattern of organisms. However, the scat-

Communicated by H.-D. Franke

V.E. McArthur · D. Koutsoubas $(-)$. N. Lampadariou

C. Dounas

Department of Technology and Management

of the Marine Environment,

Institute of Marine Biology of Crete,

P.O. Box 2214, 71003, Heraklion, Crete, Greece

e-mail: drosos@imbc.gr tered distribution of lagoons and the specific set of factors structuring each one make each system very much unique (Barnes 1980). Increasingly, lagoons are highly valued habitats not only on account of their aesthetic importance and the varied and rare species they support, but also due to the expanding recognition of their economic value. In particular, the shallow lagoons along Mediterranean coastlines are used intensively for aquaculture or fisheries (Kapetsky 1984; Ardizzone et al. 1988). In such shallow ecosystems meiobenthos, which have been shown to have a high tolerance for brackish waters (Santos et al. 1996), is thought to play a more important role than macrobenthos with respect to energy flow and biogeochemical processes (Warwick et al. 1979; Warwick 1981; Castel 1992). Additionally, in these temporally highly eutrophic areas, macrofauna may be absent at certain times of the year, and bioturbation - and the consequent maintenance of oxic conditions in the sediment surface - may be dependent entirely on the meiobenthos (Villano and Warwick 1995).

Over the last two decades the scope of meiofaunal research has been extended to include studies of meiofaunal density and distribution and the related environmental factors in lagoons and estuaries (Coull 1985, 1988; Castel et al. 1989, 1990; Castel 1992). However, despite the increased interest in meiofauna, habitats such as brackish and lagoonal waters still remain less studied than other marine environments (Castel 1992). As far as Mediterranean lagoons are concerned, research has only been carried out in the western and central basin - Lac de Tunis (Vitiello and Aissa 1979), France (Castel 1992 and references therein) and Italy (Ceccherelli and Cevidalli 1981) - while no similar studies exist for the eastern basin.

The present study was part of a project investigating the structure and functioning of Gialova lagoon for the development of an integrated economic, social and environmental management policy consistent with preservation of its biological function. Preliminary results on physico-chemical parameters of the water column and sediment and macrobenthic population structure have already been published (Koutsoubas et al. 1997a,b; Arvanitidis et al. 1999). The 
objectives of this study were: (1) to determine the composition and dynamics of the meiofaunal community in an eastern Mediterranean lagoon (Gialova lagoon, Greece) using the major taxonomic groups, and (2) to investigate the key environmental variables affecting the structure and distribution of this community.

\section{Materials and methods}

Study area

Gialova lagoon is situated on the south-west coast of Greece, adjacent to the Ionian Sea (Fig. 1) and has been classified as a Special Area of Conservation under the 1992 EC Habitats Directive. It covers an area of $2.5 \mathrm{~km}^{2}$, with a maximum depth of $1 \mathrm{~m}$ and is isolated almost entirely from the sea, with saltwater entering through the adjoining Navarino Bay via a small channel $(100 \mathrm{~m}$ long, $10 \mathrm{~m}$ wide and $1.2 \mathrm{~m}$ deep). Fluvial input is by two small inlets to the east of the lagoon (Fig. 1).

Field sampling and processing

A series of samples from Gialova lagoon were collected from seven stations that were identified as representing characteristic features of the lagoon (stations A and B adjacent to the marine channel, stations $\mathrm{C}, \mathrm{D}, \mathrm{E}$ and $\mathrm{G}$ within the main body of the lagoon, station $F$ next to the freshwater inlets; Fig. 1). At each station three replicate samples were taken using a HYDROBIOS sediment corer, to a depth of $2 \mathrm{~cm}$ since from pilot samples more than $90 \%$ of the meiofauna was present in this sediment layer. The internal diameter of the core was $7 \mathrm{~cm}$ (area: $38.5 \mathrm{~cm}^{2}$ ). Fauna in the sediment (first relaxed with $\mathrm{MgCl}_{2}$ ) were fixed in neutralised $10 \%$ formalin and stained with rose bengal (the overlying water was sieved through a $45-\mu \mathrm{m}$ mesh net).

Additional sediment and water samples were taken at each station for analysis of abiotic parameters: temperature, redox potential, sediment particulate organic carbon, chlorophyll $a$, phaeopigments, mean diameter of sediment particles, silt-clay percentage, salinity (practical salinity scale), dissolved oxygen, $\mathrm{pH}$, ammonia, nitrates, nitrites, phosphates and silicates. The sampling was repeated seasonally from summer 1995 to spring 1996. Samples of particulate organic carbon, chlorophyll $a$, phaeopigments and nutrients were frozen at $-20^{\circ} \mathrm{C}$ until analysis. Estimations of the above parameters were obtained according to standard procedures (Yentsch and Menzel 1963; Strickland and Parsons 1972; Grasshoff et al. 1983; Parsons et al. 1984). Sediment particle size analysis used wet sieving through a 63 $\mu \mathrm{m}$ mesh to separate the coarse and fine fractions and \% silt-clay was further determined by pipette analysis (Buchanan 1984).

Meiofauna were extracted from the sediment using the methods of Pfannkuche and Thiel (1988) for centrifugation in a colloidal silica solution (Ludox) with a specific gravity of 1.15. Meiofauna in the supernatant were rinsed in distilled water and washed off the sieve with $10 \%$ formalin and stored. The extraction efficiency was checked manually and proved to be more than $95 \%$ for most of the meiofaunal groups. Samples were examined under a binocular microscope on a grided petri dish, and major taxa identified and counted.

In this study the methodology adopted was to identify meiofaunal animals to major taxonomical groups: Foraminifera [only soft-bodied foraminiferans, as shelled individuals are not removed by the Ludox method (Schwinghamer 1981)], Ciliata, Cnidaria, Turbelaria, Nemertina, Gnathostomulida, Nematoda, Rotifera, Gastrotricha, Annelida, Gastropoda, Bivalvia, Ostracoda, Harpacticoida, Copepoda, Amphipoda, Diptera larvae, Bryozoa, Holothuroidea and Ascidiacea. The highly labour-intensive methods of identifying meiofauna to species level not only require a great deal of time and expertise, but may be too sensitive (Gee et al. 1992) as the natural fluctuations in meiofaunal species density and distribution can mask the larger impacts of unnatural events (Warwick and Clarke 1993). Furthermore, experiments analysing successively

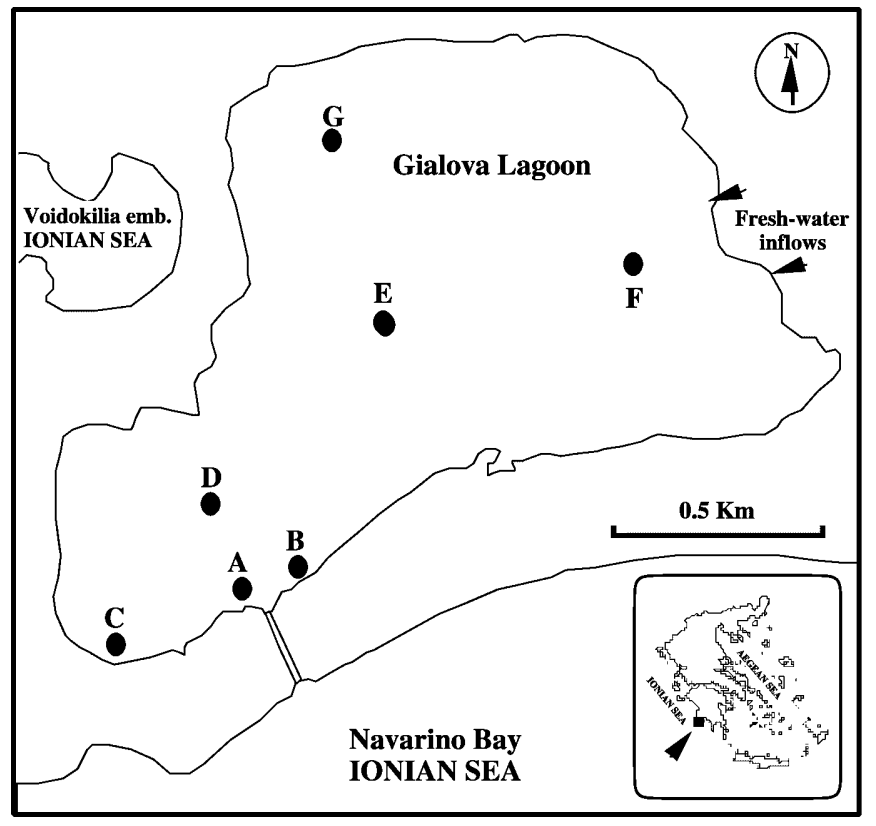

Fig. 1 Map of Gialova lagoon, indicating seasonal sampling stations for abiotic parameters and meiofauna analysis

higher taxonomic groups, in both macro- and meiofauna, show disturbance effects to be equally detectable using the highest taxonomic levels (Heip et al. 1988; Herman and Heip 1988; Warwick 1988; Warwick et al. 1990; Warwick and Clarke 1993).

\section{Data analysis}

Meiobenthic community structure and dynamics were analysed by means of number of taxa and density (mean number of individuals per $10 \mathrm{~cm}^{2}$ ). The Mann-Whitney test was used to analyse differences in the distribution of taxa and density among stations (over all seasons) and among seasons (over all stations).

Following the methods of Clarke (1993) using the PRIMER software package (Plymouth Marine Laboratory, UK), biological data (mean of three replicates from each station) were analysed after fourth root transformation (Zar 1996). Cluster analysis (group average) and non-metric multidimensional scaling (MDS) (Kruskal and Wish 1978) based on the Bray-Curtis similarity index between stations (Clarke and Green 1988) were used. These analyses were applied to both total and seasonal biological data. The significance of the resulting groups was tested using the ANOSIM test (Clarke 1993). The taxa contributing to the dissimilarities between the groups of stations, distinguished by the multivariate analyses, were determined using the SIMPER similarities percentages procedure (Clarke 1993). Environmental variables best correlated with the multivariate pattern of the meiobenthic community were evaluated by means of the BIO-ENV analysis as proposed by Clarke and Ainsworth (1993). Additionally, Spearman's rank correlation coefficient $(\rho)$ was used to determine any significant correlation between the univariate measures of the meiofaunal community (number of taxa, density, mean percentage of the most abundant taxa such as nematodes and copepods) and the environmental variables over all stations and sampling periods.

\section{Results}

\section{Abiotic data}

The environmental data (Table 1) showed large variations; however, some distinct temporal and spatial trends 
ดัช์

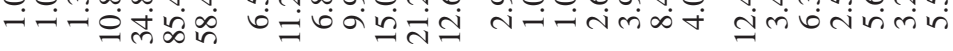

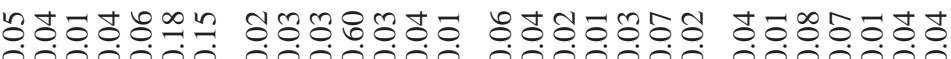

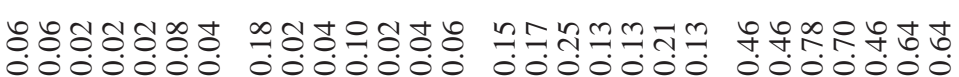

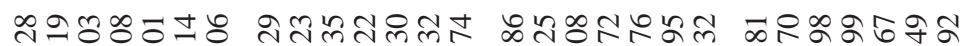

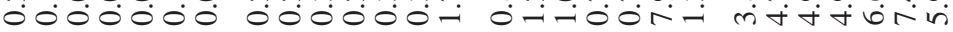

ษ

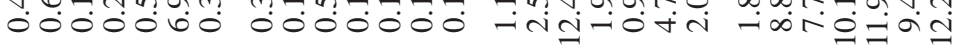

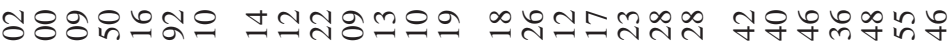

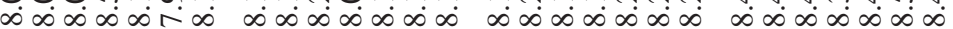

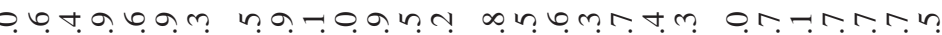
risos on

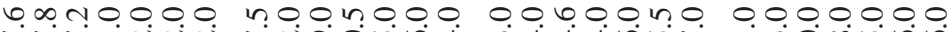

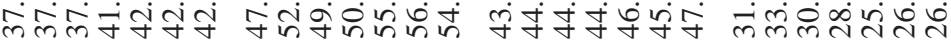

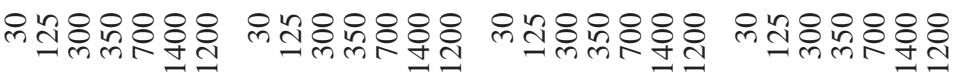

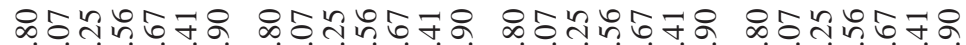
की

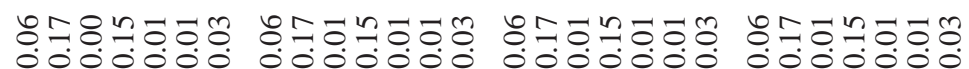

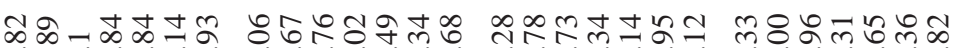

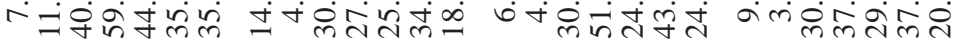

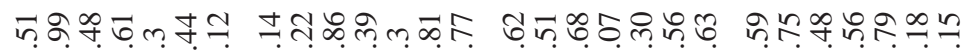

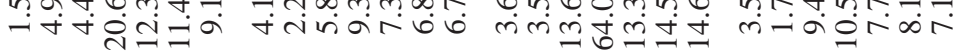

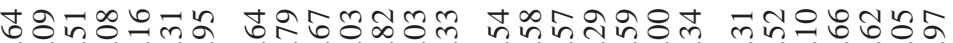

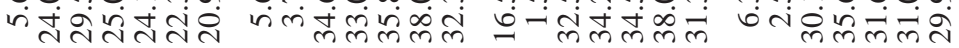

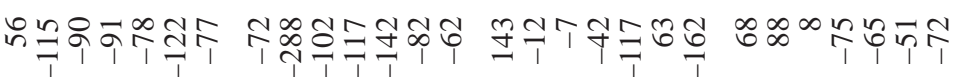

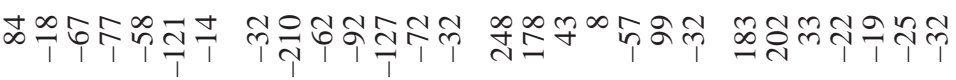

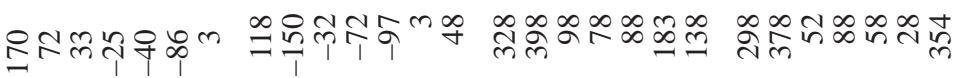

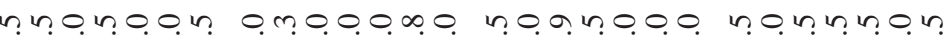

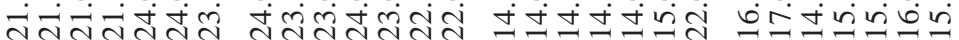

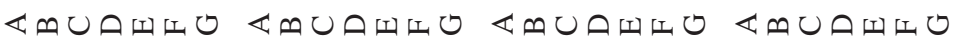
离 吾 
Fig. 2 Seasonal variation in density of major meiobenthic taxa at sampling stations in Gialova lagoon. Values shown are mean number of individuals per $10 \mathrm{~cm}^{2} \pm$ SE. Combined group 'Other' contains cnidarians, nemertines, rotifers, amphipods, dipteran larvae, bryozoans, holothuroids, ascidians and unknowns

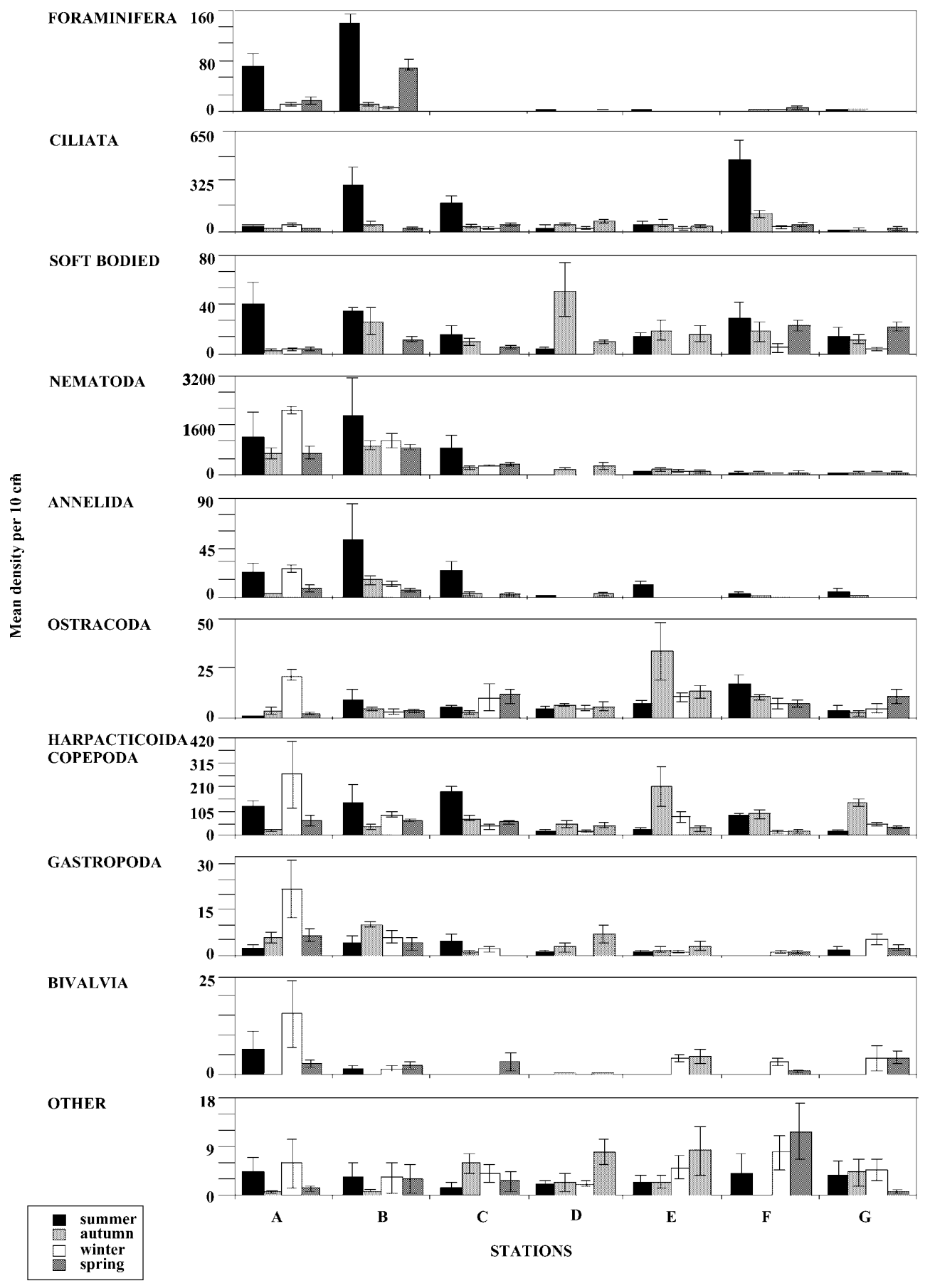

were seen. The variables showing the clearest temporal trends were temperature, redox potential at all depths, salinity (increasing, as would be expected, in summer and autumn), dissolved oxygen (lowest in the summer), and nutrients (ammonia, nitrate and nitrite) which all reached a maximum in the spring. Spatial trends could be seen for sediment particulate organic carbon, chlorophyll $a$ and phaeopigments, which had a tendency to be much higher in stations $\mathrm{C}, \mathrm{D}, \mathrm{E}, \mathrm{F}$ and $\mathrm{G}$ than $\mathrm{A}$ and $\mathrm{B}$. A gradient similar to this could be seen in the silt-clay distribution with $\mathrm{C}, \mathrm{E}, \mathrm{F}$ and $\mathrm{G}$ having the highest percentage followed by $\mathrm{D}$, with $\mathrm{A}$ and $\mathrm{B}$ consistently the lowest.
Faunal data

A total of 21 major taxa, composed of over 180000 individuals, were identified from Gialova lagoon during the four sampling periods over summer 1995 to spring 1996. The collected meiofauna was largely composed of nematodes and copepods (Fig. 2) and nematodes dominated about half the collected 28 samples. Mean number of taxa, density of all meiobenthic taxa and mean percentage of the most abundant taxa (nematodes and copepods) for all the sampling sites over the sampling period from Gialova lagoon are presented in Table 2. 
Table 2 Mean number of taxa, density (mean number of individuals per $10 \mathrm{~cm}^{2}$ ) of all meiobenthic taxa, and mean percentage of most abundant taxa (nematodes and copepods) for all sampling sites over the sampling period from Gialova lagoon

\begin{tabular}{|c|c|c|c|c|c|}
\hline & Station & $\begin{array}{l}\text { Mean no. } \\
\text { of taxa }\end{array}$ & $\begin{array}{l}\text { Mean no. } \\
\text { of individuals } \\
\text { per } 10 \mathrm{~cm}^{2}\end{array}$ & $\begin{array}{l}\text { Mean } \% \\
\text { nematodes } \\
\text { per } 10 \mathrm{~cm}^{2}\end{array}$ & $\begin{array}{l}\text { Mean } \% \\
\text { copepods } \\
\text { per core }\end{array}$ \\
\hline Summer & $\begin{array}{l}\text { A } \\
\text { B } \\
\text { C } \\
\text { D } \\
\text { E } \\
\text { F } \\
\text { G }\end{array}$ & $\begin{array}{r}14 \\
11 \\
10 \\
13 \\
13 \\
9 \\
11\end{array}$ & $\begin{array}{r}1421 \\
2488 \\
1231 \\
37 \\
119 \\
610 \\
37\end{array}$ & $\begin{array}{r}63.7 \\
64.8 \\
57.3 \\
18.1 \\
30.3 \\
4.3 \\
27.0\end{array}$ & $\begin{array}{r}13.9 \\
4.9 \\
18.3 \\
12.7 \\
31.1 \\
13.2 \\
17.3\end{array}$ \\
\hline Autumn & $\begin{array}{l}\text { A } \\
\text { B } \\
\text { C } \\
\text { D } \\
\text { E } \\
F \\
\text { G }\end{array}$ & $\begin{array}{r}9 \\
9 \\
11 \\
8 \\
10 \\
7 \\
10\end{array}$ & $\begin{array}{r}647 \\
1003 \\
250 \\
275 \\
403 \\
225 \\
177\end{array}$ & $\begin{array}{r}93.9 \\
86.5 \\
59.9 \\
48.0 \\
23.4 \\
4.0 \\
12.2\end{array}$ & $\begin{array}{r}2.5 \\
3.1 \\
22.7 \\
13.8 \\
54.5 \\
37.3 \\
76.3\end{array}$ \\
\hline Winter & $\begin{array}{l}\text { A } \\
\text { B } \\
\text { C } \\
\text { D } \\
\text { E } \\
\text { F } \\
\text { G }\end{array}$ & $\begin{array}{r}13 \\
10 \\
7 \\
8 \\
10 \\
7 \\
10\end{array}$ & $\begin{array}{r}2403 \\
1101 \\
255 \\
17 \\
165 \\
47 \\
83\end{array}$ & $\begin{array}{l}84.4 \\
89.7 \\
80.6 \\
22.8 \\
38.4 \\
14.6 \\
27.6\end{array}$ & $\begin{array}{r}10.3 \\
8.0 \\
8.3 \\
11.2 \\
43.4 \\
13.3 \\
48.6\end{array}$ \\
\hline Spring & $\begin{array}{l}\text { A } \\
\text { B } \\
\text { C } \\
\text { D } \\
\text { E } \\
\text { F } \\
\text { G }\end{array}$ & $\begin{array}{l}14 \\
12 \\
10 \\
14 \\
10 \\
12 \\
12\end{array}$ & $\begin{array}{r}748 \\
958 \\
379 \\
332 \\
133 \\
103 \\
85\end{array}$ & $\begin{array}{l}82.0 \\
83.0 \\
74.3 \\
55.5 \\
28.2 \\
141 \\
23.6\end{array}$ & $\begin{array}{r}10.5 \\
5.8 \\
11.2 \\
7.4 \\
15.2 \\
7.8 \\
23.6\end{array}$ \\
\hline
\end{tabular}

Strong peaks could be seen in summer 1995 for foraminiferans, ciliates, soft-bodied groups (turbelarians, gnathostomulids, gastrotrichs), nematodes and annelids (Fig. 2). Ostracods and to a certain extent copepods reached peak concentration in autumn 1995. Winter 1995 and spring 1996 were the periods of increased densities in the combined taxa group 'other' (composed of cnidarians, nemertines, rotifers, amphipods, dipteran larvae, bryozoans, holothuroids, ascidians and unknowns). Stations A and B consistently had higher numbers of foraminiferans, nematodes, annelids, and to some extent molluscs (gastropods and bivalves) than the remaining stations (Fig. 2).

\section{Structural analysis}

Temporal and spatial trends in the univariate measures of the meiofaunal community could be observed in Gialova lagoon (Table 3). The distribution of taxa in the stations during the autumnal sampling was found to be significantly different from the one during the summer sampling, indicating a drop in the number of taxa in certain stations from summer to autumn and a subsequent rise from winter to spring sampling (Table 3, A). Significant spatial differences were found for three univariate measures: density, percentage of nematodes and percentage of copepods (Table 3, B-D). The distribution of density values in stations $\mathrm{A}$ and $\mathrm{B}$ over all sampling periods was significantly different from the one in stations D, E, F and $\mathrm{G}$; station $\mathrm{C}$ had also significantly different density values from stations $A, D, E, F$ and $G$ but rather was similar to station B (Table 3, B). Based on these results, the seven stations of the lagoon could be divided into two distinct groups: the first group comprises stations A and $\mathrm{B}$ (to which station $\mathrm{C}$ can be attached), and the second comprises stations D, E, F and G. A similar grouping comes from the comparison of the distribution of the percentages of nematodes in the stations over all sampling periods, but the results from the distribution of the percentages of the copepods give a more complicated picture.

Cluster analysis using means for all stations over the four seasons produced the same pattern, clearly grouping stations $\mathrm{A}$ and $\mathrm{B}$ together across all seasons (Fig. 3). Two clear groups emerged from all seasonal clusterings, grouping stations next to the marine channel opening (stations $\mathrm{A}$ and $\mathrm{B}$ ), and the rest in the main body of the lagoon (C, D, E, F and G). The MDS plot (not shown) gave a high stress value (0.18), indicating that this twodimensional plot was not of much value.

The clustering was repeated on seasonally separated groupings and compared to seasonal ordination plots with the lowest stress (all less than 0.02) (Fig. 4); a level of $70-75 \%$ was selected as a cutoff point for groups. In the summer sample the groups subdivided further into 
Table 3 Temporal and spatial trends in univariate measures of the meiofaunal community in Gialova lagoon. Significant differences (Mann-Whitney test) found: $A$ between seasons for mean number of taxa; $B$ between stations for density (mean number of individuals per $10 \mathrm{~cm}^{2}$ ) of all meiobenthic taxa; $C$ between stations for mean percentage of nematodes; $D$ between stations for mean percentage of copepods. $n d$ No significant differences; * $P<0.05$

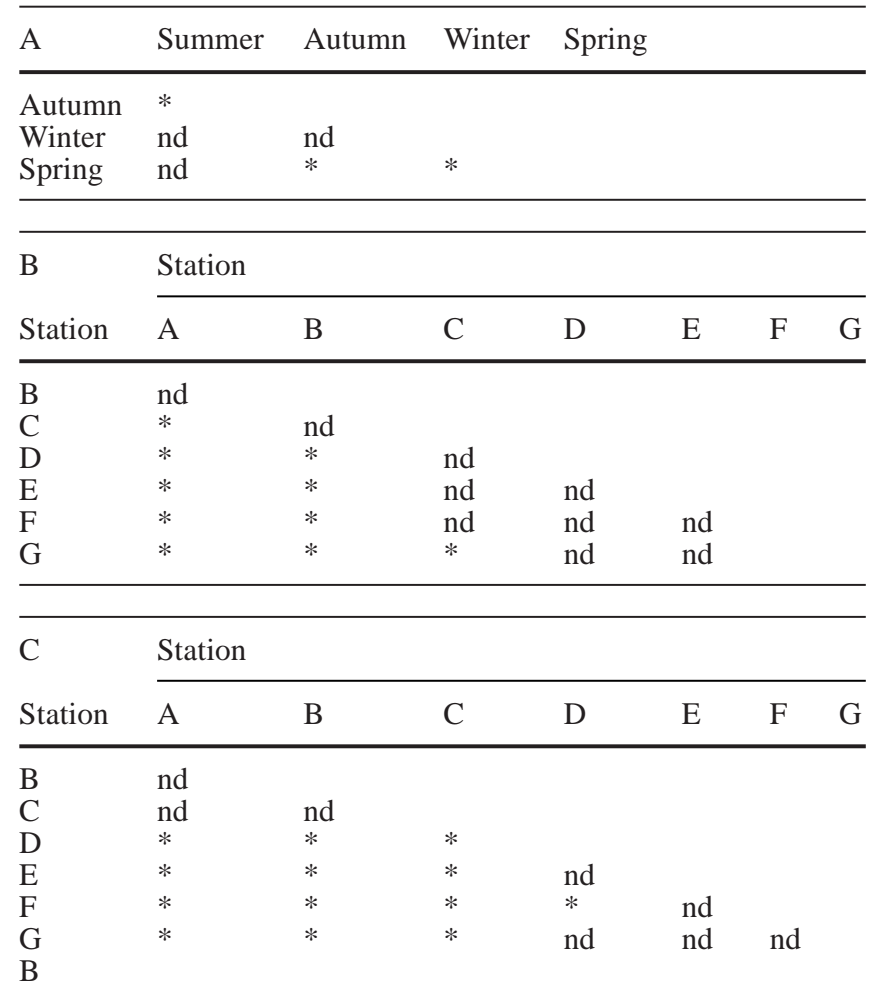

\begin{tabular}{llllllll}
\hline D & \multicolumn{2}{ll}{ Station } & & & & & \\
\cline { 2 - 7 } Station & A & B & C & D & E & F & G \\
\hline B & nd & $*$ & & & & & \\
C & nd & $*$ & & & & & \\
D & nd & $*$ & nd & & & & \\
E & $*$ & $*$ & $*$ & $*$ & & & \\
F & nd & $*$ & $*$ & nd & nd & & \\
G & $*$ & $*$ & nd & $*$ & nd & nd & \\
\hline
\end{tabular}

three groups, the first formed by stations A, B and C, the second by stations $\mathrm{D}, \mathrm{E}$ and $\mathrm{G}$, and the third group composed of $\mathrm{F}$ coming off at a lower similarity level. For the autumn sample only two groups could be distinguished: those near the marine channel (A and B) and the rest. Similar to the autumn sample, only two groups were clearly formed in the winter. For the spring sampling, three distinct groups were produced, clustering stations $\mathrm{A}$ and $\mathrm{B}$ together, $\mathrm{C}$ and $\mathrm{D}$ and the final group which contained stations E, F and G. All groupings were supported by Anosim tests with significance level of less than 5\% (Clarke 1993) (not shown here).

Five taxa accounted for most of the dissimilarities between the stations over most of the seasons; these were in order of importance: nematodes, copepods, ciliates, turbellarians and ostracods, apart from the autumn period

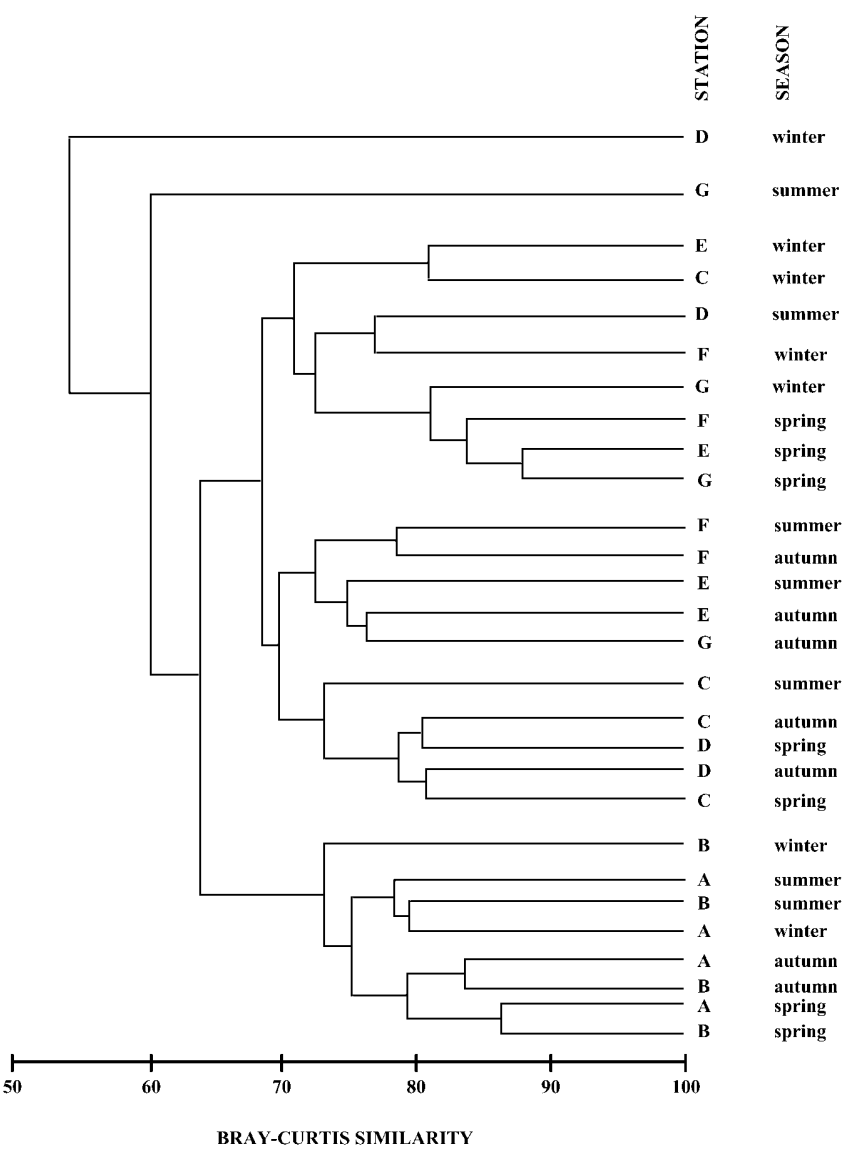

Fig. 3 Similarity dendrogram of all sites over the year (mean meiofaunal densities)

when they were replaced by nematodes, copepods, ostracods, dipteran larvae and ciliates (in order of importance). These groups accounted for $71.99 \%$ (summer), $86.32 \%$ (autumn), $76.90 \%$ (winter) and $68.90 \%$ (spring) of the observed dissimilarities.

The results of the BIO-ENV analysis are summarised in Table 4. Some of the environmental factors were highly correlated; for these the BIO-ENV was run twice, using all correlated variables, and using only one correlated variable. However, in all cases the presence of only one of the correlated variables did not alter the output. For completeness, all the variables are shown and correlations indicated in Table 4. Harmonic Spearman's coefficient values were found to be close to 0.8 in all sampling periods, thus indicating strong relationships between multivariate meiofaunal distribution pattern and the measured environmental variables. The combination of variables which give rise to the largest rank correlation between the meiofauna and the environmental variables in the summer sample were redox potential, distance to the channel, salinity, and concentration of ammonia, nitrate and phosphate. Chlorophyll $a$, phaeopigments, distance to the channel and silicate concentration were important for the autumn sample. Many environmental factors gave high values for the winter sample 
Fig. 4a Seasonal Bray-Curtis similarity dendrograms of stations. (b) Seasonal multidimensional scaling $(M D S)$ ordination plots of stations. (Clustering groups superimposed upon ordinations) (a) Cluster

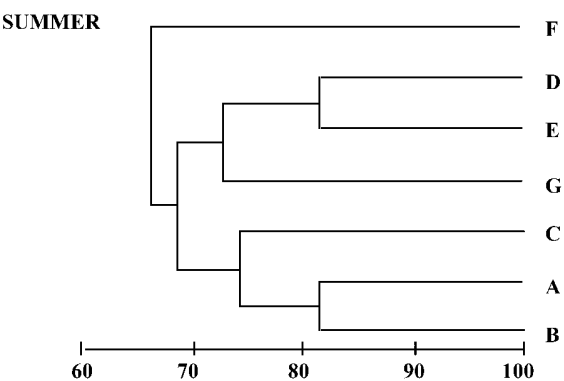

AUTUMN

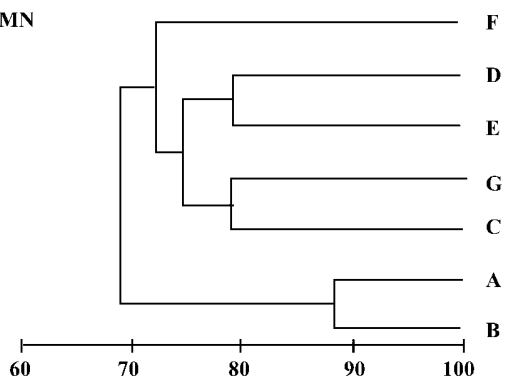

WINTER

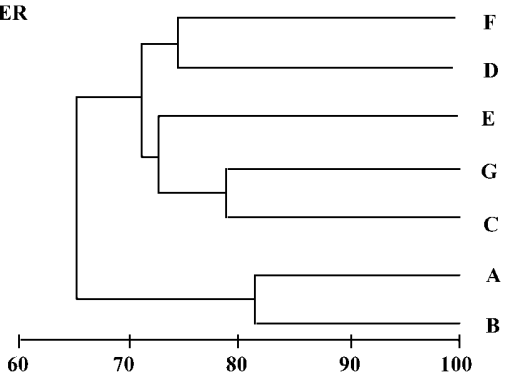

SPRING

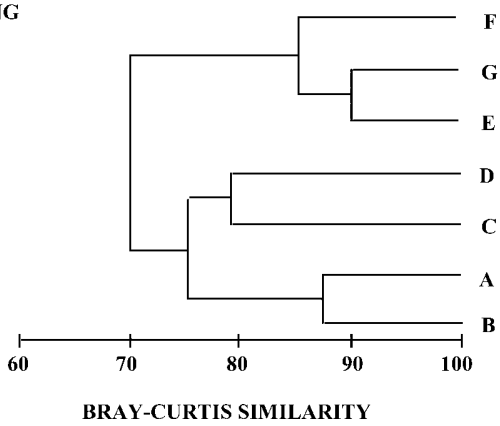

(b) MDS
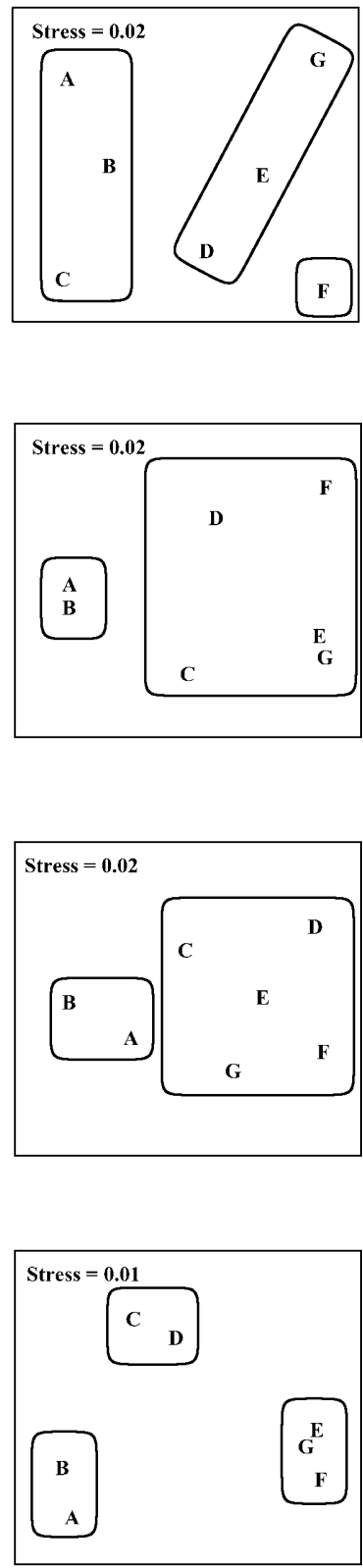

(organic carbon, chlorophyll $a$, phaeopigments, silt-clay percentage, distance to the channel, salinity and silicate), and for the spring sample relationships for meiofaunal density were found between redox potential, organic carbon, distance to the channel, salinity and silicate.

\section{Discussion}

Stations in Gialova lagoon supported a maximum of 14 meiofaunal taxa with densities ranging from 17 to 2488 individuals per $10 \mathrm{~cm}^{2}$. The meiofaunal densities encountered in Gialova lagoon were within ranges reported from other lagoons (Phillips and Fleeger 1985; Escaravage and Castel 1989; Castel et al. 1990) and estuarine habitats (Lasserre et al. 1976; Coull 1985; Gourbault and RenaudMornant 1990). Nematodes were the most abundant taxa in stations close to the marine channel (A and $\mathrm{B})$, ranging between 60 and $90 \%$ of the identified meiofauna; the remaining inner stations (C, D, E, F and G) contained fewer nematodes but higher numbers of copepods, with the latter usually being the dominating taxa in these stations (range $10-70 \%)$.

The distribution and density of most of the meiofaunal taxa encountered in the Gialova lagoon varied both across the lagoon and over the four sampling periods, but 
Table 4 Summary of results from BIO-ENV analysis. Environmental factors showing the highest correlations between meiofaunal distributions, for the complete year and four seasons. Chl- $a$ chlorophyll $a$; Dist distance to marine channel; $m d$ mean diameter of sediment particles; $P O C$ particulate organic carbon; Phaeop phaeopigments; Re-

Mean abundance of all seasons

1

2

3

4

5

Mean summer abundance 1

2

3

4

5

6

7

Mean autumn abundance 1

2

3

4

5

Mean winter abundance

2

3

4

5

6

7

8

Mean spring abundance

2

3

4

5
Chl-a

(0.352)

Chl-a, Dist

(0.502)

Chl-a, Dist, $\mathrm{SiO}_{4}$

(0.533)

Chl-a, Phaeop, Dist, $\mathrm{SiO}_{4}$

(0.559)

Chl-a, Phaeop, s-c\%, Dist, $\mathrm{SiO}_{4}$ (0.528)

$\mathrm{SiO}_{4}$

(0.607)

Redox0, $\mathrm{SiO}_{4}$

(0.703)

$\mathrm{Sal}, \mathrm{NH}_{4}, \mathrm{PO}_{4}$

(0.721)

$\mathrm{Sal}, \mathrm{NH}_{4}, \mathrm{NO}_{3}, \mathrm{PO}_{4}$

(0.718)

Dist, $\mathrm{Sal}, \mathrm{NH}_{4}, \mathrm{NO}_{2}, \mathrm{PO}_{4}$

(0.743)

Redox0, Dist, Sal, $\mathrm{NH}_{4}, \mathrm{NO}_{3}, \mathrm{PO}_{4}$

(0.749)

Redox0, Dist, $\mathrm{Sal}, \mathrm{NH}_{4}, \mathrm{NO}_{2}, \mathrm{NO}_{3}, \mathrm{PO}_{4}$

(0.738)

dox 0 redox potential at $0 \mathrm{~cm}$; Redox 2 redox potential at $2 \mathrm{~cm}$; Redox 4 redox potential at $4 \mathrm{~cm}$; $\mathrm{Sal}$ salinity; $s-c \%$ silt-clay $\%$. Variables with correlations of over 0.80 (Pearson's correlation coefficient) are as follows: Redox 0 and Redox 2 , Redox 2 and Redox 4, md and s-c\%, dissolved oxygen and $\mathrm{pH}$, nitrate and nitrite, and phosphate and silicate
Dist

(0.634)

Phaeop, Dist

(0.650)

Phaeop, Dist, $\mathrm{SiO}_{4}$

(0.692)

Chl-a, Phaeop, Dist, $\mathrm{SiO}_{4}$

(0.722)

Chl-a, Phaeop, s-c\%Dist, $\mathrm{SiO}_{4}$ (0.663)

Chl-a

(0.567)

Chl-a, Dist

(0.739)

POC, Chl-a, Dist

(0.828)

POC, Chl-a, Sal, $\mathrm{SiO}_{4}$

(0.840)

POC, Chl-a, Phaeop, $\mathrm{Sal}_{,} \mathrm{SiO}_{4}$

(O.835)

POC, Chl-a, Phaeop, Dist, $\mathrm{Sal}_{,} \mathrm{SiO}_{4}$

(0.848)

POC, Chl-a, Phaeop, s-c\%, Dist, Sal, $\mathrm{SiO}_{4}$ (0.858)

POC, Chl-a, Phaeop, md, s-c\%, Dist, $\mathrm{Sal} \mathrm{SiO}_{4}$ (0.792)

Sal

(0.747)

Redox $4, \mathrm{NO}_{3}$

(0.809)

Redox2, Dist, $\mathrm{NO}_{3}$

(0.840)

Redox2, Dist, $\mathrm{Sal}, \mathrm{NO}_{3}$

(0.846)

Redox4, POC, Dist, Sal, $\mathrm{NO}_{3}$

(0.846)
Phaeop

(0.332)

Phaeop, Dist

(0.445)

Chl-a, Phaeop, Dist

(0.513)

Chl-a, s-c\%, Dist, $\mathrm{SiO}_{4}$

(0.469)

Chl-a, Phaeop, md, Dist, $\mathrm{SiO}_{4}$ (0.465)

Dist

(0.564)

Redox0, Dist

(0.640)

Redox0, $\mathrm{Sal}, \mathrm{PO}_{4}$

(0.694)

Dist, $\mathrm{Sal}, \mathrm{NO}_{2}, \mathrm{SiO}_{4}$

(0.717)

Dist, Sal, $\mathrm{NH}_{4}, \mathrm{NO}_{3}, \mathrm{PO}_{4}$

(0.731)

Redox0, Dist, $\mathrm{Sal}, \mathrm{NH}_{4}, \mathrm{NO}_{2}, \mathrm{NO}_{3}, \mathrm{PO}_{4}$ (0.740)

Redox0, Dist, $\mathrm{Sal}, \mathrm{NH}_{4}, \mathrm{NO}_{2}, \mathrm{NO}_{3}, \mathrm{PO}_{4}$ (0.714)

Chl-a, Dist

(0.615)

Chl-a, Dist, $\mathrm{SiO}_{4}$

(0.685)

Phaeop, Dist, Sal, $\mathrm{PO}_{4}$

(0.674)

Chl-a, Phaeop, Dist, $\mathrm{Sal}, \mathrm{SiO}_{4}$

(0.650)

Chl-a

(0.523)

POC, Phaeop

(0.607)

Phaeop, md, Dist

(0.783)

POC, Chl-a, Phaeop, Dist

(0.823)

Chl-a, Phaeop, s-c\%, Sal, $\mathrm{SiO}_{4}$

(0.831)

POC, Chl-a, Phaeop,s-c\%, Sal, $\mathrm{SiO}_{4}$

(0.814)

POC, Chl-a, Phaeop, md, Dist, $\mathrm{Sal}, \mathrm{SiO}_{4}$ (0.825)

POC, Chl-a, Phaeop, md, Dist, $\mathrm{Sal}, \mathrm{PO}_{4} \mathrm{SiO}_{4}$ (0.786)

$\mathrm{NO}_{3}$

(0.677)

$\mathrm{Sal}, \mathrm{NO}_{3}$

(0.796)

Redox 2, Sal, $\mathrm{NO}_{3}$

(0.832)

POC, Dist, Sal, $\mathrm{NO}_{3}$

(0.825)

Redox2, Redox4, Dist, Sal, $\mathrm{NO}_{3}$ (0.839) 
the real fluctuations occurred as a spatial factor. This is further supported by the finding that the distance from the canal opening was negatively correlated with the density of all meiobenthic organisms (Spearman's $\rho=-0.71, P<<0.01)$ as well as with the percentage of nematodes $(\rho=-0.9, \mathrm{P}<<0.01)$ over all sampling periods. Conversely, the percentage of copepods was positively correlated with the distance from the channel $(\rho=0.56$, $\mathrm{P}<<0.01$ ). Taking into account the results of the uni- and multivariate analyses, two strong divisions can be distinguished across the lagoon: a first narrow zone which is defined by the area into which the channel opens (marine-influenced) and represented by stations $\mathrm{A}$ and $\mathrm{B}$; and a second zone in the most isolated and 'lagoonal' area of Gialova, typically formed from stations D, E and G (station $\mathrm{F}$ is clustered within this group in most of the sampling seasons). This gradient from marine-influenced to completely lagoonal has also been observed in this lagoon for macrofauna (Koutsoubas et al. 1997b) and has been reported in other Mediterranean lagoons (Nicolaidou et al. 1988; Guelorget and Perthuisot 1992; Lardicci et al. 1997). Station C was within the first group during the summer sampling and within the second group during autumn and winter sampling. During the spring sampling station, station $\mathrm{C}$ was clustered along with station $\mathrm{D}$, forming a third group, which could be considered as a transitional zone between the first and the second zone. Similar results have also been observed for the macrofauna (Koutsoubas et al. 1997b), although in that study the transitional zone is apparent during summer.

The dominant taxa responsible for the station groupings are those meiofaunal groups typically found in large numbers in many marine environments, namely nematodes, copepods, ciliates, ostracods and soft-bodied animals. Together these taxa account for some $80 \%$ of the observed dissimilarities between the stations. They do this largely through variation in the numbers found in each of the stations. Stations can again be zoned on the basis of how many individuals of each of these taxa they contain; zone 1 is dominated by nematodes (between 63 and $89 \%$ of the individuals collected), while the copepodes were fewer (2-13.9\% of the individuals collected); zone 2 was composed of similar numbers of nematodes and copepods (ranging from 2 to $50 \%$ and 7 to $50 \%$ respectively).

In addition to the strong spatial dominance in taxa distribution, patterns in distribution and density of meiofauna also change over the four sampling seasons. During the summer the lagoonal community is rich; there follows a drop in taxa number during the autumn which is possibly related to the 'dystrophic crisis' observed in this lagoon during the late summer and which led to extensive mortality of macrofauna in large areas of the lagoon (Dounas and Koutsoubas 1996). However, mortality of a similar extent was not observed for meiofauna which are more capable of recovering from anoxia events than macrofauna, probably due to their rapid generation time (Heip et al. 1988). In the subsequent sam- pling seasons though there is an increase in the number of taxa which is more significant during the spring sampling.

Of the many environmental variables shown to be highly correlated with the temporal and spatial distribution of meiofauna in Gialova lagoon, some seem more determining than others. Salinity (and its relationship to temperature) has been considered to be the main environmental structuring factor in lagoonal habitats (Barnes 1980; Coull 1985; Santos et al. 1996). This is supported here as the distributional pattern of the meiofaunal community, in three of the four seasons over the sampling period (summer, winter, spring), could be related to a change in salinity from the buffered marine zone to the hyperhaline zone of the central lagoon. Distance from the sea appears in all seasons to be a prominent factor in explaining the gradients of the meiofaunal community. The theory of 'confinement', which is related to the rate of exchanges with the open sea and the hydrodynamic pattern of the basin (Guelorget and Perthuisot 1983), has been successfully applied to lagoonal ecosystems for the explanation of the structure of both the macro- (Nicolaidou et al. 1988; Guelorget and Perthuisot 1992; Koutsoubas et al. 1997b) and meiofauna (Castel et al. 1990; Guelorget et al. 1994), and seems to account also for meiofaunal community structure in Gialova lagoon.

Food, both in its raw nutrient forms (ammonia, nitrate, phosphate) and as organic material and microphytobenthos, was found to play an important role in meiofaunal distribution in Gialova lagoon throughout the year. Research has shown that nutrient limitation in lagoons is a complex matter; in particular nitrogen limitation is important (Nixon 1982; Taylor et al. 1995). During the summer and spring, raw nutrients are more important in Gialova, reflecting the growth stage of meiofaunal food (bacteria, microphytoplankton) and perhaps limiting distribution and density. In autumn and winter, correlations were found with photosynthetic pigments and organic matter, indicating a strong influence of algae on meiofaunal feeding resources which Giere (1993) suggests could have particular importance for microalgal-based ciliates, nematodes and copepods. It is likely that the distribution of meiofauna in Gialova lagoon is related to the high primary production, but patchiness due to small-scale variability between adjacent areas of the sediment and seasonal blooms as found by Giere (1993) in marine sediments should not be excluded.

Low oxygen levels and anoxic crises are typical of lagoon waters. In particular, warm periods and the associated superdensity of organic matter in this highly eutrophic habitat often lead to 'dystrophic crises' (Barnes 1980; Guelorget and Perthuisot 1992). Redox potential was a significant factor during the summer and spring. However, the measure of oxygen availability in the sediments may not be the best indicator of low oxygen, especially in the autumn sampling when the entire body of the lagoon shows negative redox values; Nixon (1982) correlates high phosphate levels released in lagoon sedi- 
ments with anoxic conditions. Interestingly, phosphate levels rose during summer and autumn, and BIO-ENV analysis indicated phosphate as a determining factor for the summer period, suggesting that oxygen was limiting distribution and density of lagoonal meiofauna.

The results obtained from the BIO-ENV analysis showed that, unlike similar types of habitat, the type of sediment was not found to exert an important role on the meiofaunal community (Castel et al. 1990; Castel 1992; Gourbault and Renaud-Mornant 1990). Spearman's tests showed a negative correlation between the silt-clay percentage and the density of all meiobenthic organisms $(\rho=-0.51, \mathrm{P}<<0.01)$ and between the same variable and the percentage of nematodes $(\rho=-0.71$, $\mathrm{P}<<0.01$ ). Additionally, the percentage of copepods was positively correlated with the silt-clay percentage $(\rho=0.56, P<<0.01)$. The above indicate that although the type of sediment may be correlated with the density values, other environmental variables produce strong gradients across the lagoon, limiting the distribution of the individuals and determining the pattern of the meiobenthic community. However, the biogenic processes and microturbating factors may be underestimated by analysing purely geological sedimentary differences (Watling 1991); thus it is likely that detritus, bacteria and water-sediment chemistry reflect more accurately the sedimentary habitat of Gialova meiofauna. In particular, the stable, flocculent organic sediments of lagoons will be of more importance to the animals dwelling in them than the gross mineral particles commonly tested by sediment analysis.

Finally, plausible explanations for large-scale structure of the meiofaunal population of Gialova lagoon lie in selections from each theory, ultimately controlled by bottom-up abiotic factors (in particular distance from the marine influence) with all their implications for r-selection, supported by the rapid generation time of most meiofaunal animals. However, on a mesoscale, localised differences (illustrated by the large variation between replicates) may reflect variety in the food density of microhabitats causing competition and mutual exclusion, thereby shaping the population distribution.

Acknowledgements The authors are most grateful to Dr. Michael McArthur and Prof. A. Eleftheriou for critical reading of the manuscript, to Dr. Christos Arvanitidis for many statistical discussions and comments on the manuscript and to Leslie Brown for extensive assistance with the sample processing. This study which forms part of the Environment Impact Assessment Program in Gialova Lagoon was partly funded by the Greek Ministry of Agriculture and the EU.

\section{References}

Ardizzone GD, Cataudella S, Rossi R (1988) Management of coastal lagoon fisheries and aquaculture in Italy. FAO Fish Tech Pap, 293. FAO, Rome

Arvanitidis C, Koutsoubas D, Dounas C, Eleftheriou A (1999) Annelid fauna of a Mediterranean lagoon (Gialova lagoon, SW Greece): community structure in a severely fluctuating environment. J Mar Biol Assoc UK 79:849-856
Barnes RSK (1980) Coastal lagoons. The natural history of a neglected habitat. Cambridge studies in modern biology, 1. Cambridge University Press, Cambridge

Buchanan JB (1984) Sediment analysis. In: Holme NM, McIntyre AD (eds) Methods for the study of the marine benthos. Blackwell, Oxford, pp 41-65

Castel J (1992) The meiofauna of coastal lagoon ecosystems and their importance in the food web. Vie Milieu 42:125-135

Castel J, Labourg PJ, Escaravage V, Auby I, Garcia ME (1989) Influence of sea-grass beds and oyster parks on the abundance and biomass patterns of meio- and macrobenthos in tidal flats. Estuarine Coast Shelf Sci 28:71-85

Castel J, Labourg PJ, Escaravage V, Thimel A (1990) Distribution quantitative du méio- et macrobenthos dans des lagunes mixohalines: influence du confinement sur le partage des ressources. Oceanol Acta 13:349-359

Ceccherelli VU, Cevidalli F (1981) Osservazioni preliminari sulla bionomia dei popolamenti meiobentonici della Sacca di Scardovari (Delta del Po), con particolare riferimento ai Nematodi ed ai Copepodi. Quad Lab Tecnol Pesca 3:265-281

Clarke KR (1993) Non-parametric multivariate analysis of changes in community structure. Aust J Zool 18:117-143

Clarke KR, Ainsworth M (1993) A method of linking multivariate community structure to environmental variables. Mar Ecol Prog Ser 92:205-219

Clarke KR, Green RH (1988) Statistical design and analysis for a 'biological effects' study. Mar Ecol Prog Ser 46:213-226

Coull BC (1985) The use of long-term biological data to generate testable hypotheses. Estuaries 8:84-92

Coull BC (1988) Ecology of marine meiofauna. In: Higgins RP, Theil H (eds) Introduction to the study of meiofauna. Smithsonian Institute Press, Washington, DC, pp 18-38

Dounas C, Koutsoubas D (1996) Environmental impact assessment of oil pollution in Navarino Bay and the Gialova Lagoon (in Greek). Technical Report, Ministry of Agriculture, Greece

Escaravage V, Castel J (1989) Application de la notion de confinement aux peuplements méiobenthiques des lagunes endiguées du Bassin d'Arcachon (côte Atlantique). Acta Ecol Ecol Gen 10:1-17

Gee JM, Austen M, DeSmet G, Ferraro T, McEvoy A, Moore S, Van Gausbeki D, Vincx M, Warwick RM (1992) Soft sediment meiofaunal community responses to environmental pollution gradients in the German Bight and at a drilling site off the Dutch Coast. Mar Ecol Prog Ser 91:289-302

Giere O (1993) Meiobenthology: the microscopic fauna in aquatic sediments. Springer, Berlin Heidelberg New York

Gourbault N, Renauld-Mornant J (1990) Micro-meiofaunal community structure and nematode diversity in a lagoonal ecosystem (Fangataufa, Eastern Tuamotu Archipelago). PSZNI Mar Ecol 11:173-189

Grasshoff K, Ehrhardt M, Kremmling K (1983) Methods of seawater analysis. Verlag Chemie, Berlin

Guelorget O, Perthuisot J-P (1983) Le domaine paralique. Expression géologiques, biologiques du confinement. Trav Lab Geol Ecol Norm Super, Paris, 16:1-136

Guelorget O, Perthuisot J-P (1992) Paralic ecosystems. Biological organisation and functioning. Vie Mileu 42:215-251

Guelorget O, Perthuisot J-P, Lamy N, Lefebvre A (1994) Structure et organisation de l'étang de Thau d'aprés la faune benthique (macrofaune, meiofaune). Relations avec le confinement. Oceanol Acta 17:105-114

Heip C, Warwick RM, Carr MR, Herman PMJ, Huys R, Smol N, Van Holsbeke K (1988) Analysis of community attributes of the benthic meiofauna of Frierfjord/Langesundfjord. Mar Ecol Prog Ser 46:171-180

Herman PMJ, Heip C (1988) On the use of meiofauna in ecological monitoring: who needs taxonomy? Mar Pollut Bull 19: 665-668

Kapetsky JM (1984) Coastal lagoons fisheries around the world: some perspectives on fishery yields and other comparative fishery characteristics. In: Kapetsky JM, Lassere JM (eds) Management of coastal lagoons fisheries. FAO Stud Rev GFCM 1(61):97-139 
Koutsoubas D, Dounas C, Petihakis G, Arvanitidis C, Triandafyllou G, Dafnomili E, Zivanovic S (1997a) Dynamic changes of physico-chemical parameters in Gialova lagoon (SW Peloponessos, Ionian Sea) (in Greek with English abstract). In: Proceedings of the 5th Hellenic Symposium on Oceanography and Fisheries, Kavala, Greece, 15-18 April 1997, National Centre for Marine Research, pp 351-352

Koutsoubas D, Arvanitidis C, Petihakis G, Drummond L, Dounas C (1997b) Structure and dynamic of the macrobenthic populations in Gialova lagoon, Ionian Sea (in Greek with English abstract). In: Proceedings of the 5th Hellenic Symposium on Oceanography and Fisheries, Kavala, Greece, 15-18 April 1997, National Centre for Marine Research, pp 309-312

Kruskal JB, Wish M (1978) Multidimensional scaling. Sage, Beverly Hills, Calif

Lardicci C, Rossi F, Castelli A (1997) Analysis of macrozoobenthic community structure after severe "dystrophic crises" in a Mediterranean coastal lagoon. Mar Pollut Bull 34:536-547

Lasserre P, Renaud-Mornant J, Castel J (1976) Metabolic activities of meiofaunal communities in semi-enclosed lagoons. Possibilities of trophic competition between meiofauna and mugiliid fish. In: Persoone G, Jaspers E (eds) Proceedings of the 10th Marine Biology Symposium, vol 2. Universa Press, Wetteren, pp 313-414

Nicolaidou A, Bourgoutzani F, Zenetos A, Guelorget O, Perthuisot J-P (1988) Distribution of molluscs and polychaetes in coastal lagoons of Greece. Estuarine Coast Shelf Sci 26:337-350

Nixon SW (1982) Nutrient dymanics, primary production and fisheries yields of lagoons. In: Lasserre P, Postma H (eds) Les lagunes côtières. Special volume of Océanol Acta, pp 357-371

Parsons TR, Maita Y, Lalli cm (1984) A manual of chemical and biological methods for seawater analysis. Pergamon Press, New York

Pfannkuche O, Thiel H (1988) Sample processing. In: Higgins RP, Thiel H (eds) Introduction to the study of meiofauna. Smithsonian Institute Press, Washington, DC, pp 134-145

Phillips FE, Fleeger JW (1985) Meiofaunal meso-scale variability in two estuarine habitats. Estuarine Coast Shelf Sci 21:745756

Santos PJP, Castel J, Souza-Santos LP (1996) Seasonal variability of meiofaunal density in the oligo-mesohaline area of the Gironde estuary, France. Estuarine Coast Shelf Sci 43:549-563
Schwinghamer P (1981) Extraction of living meiofauna from marine sediments by centrifugation in a silica sol-sorbital mixture. Can J Fish Aquat Sci 38:476-478

Strickland JDH, Parsons TR (1972) A practical handbook of seawater analysis. Bull Fish Res Bd Can 167:1-310

Taylor D, Nixon S, Granger S, Buckley B (1995) Nutrient limitation and the eutrophication of coastal lagoons. Mar Ecol Prog Ser 127:235-244

Villano N, Warwick RM (1995) Meiobenthic communities associated with the seasonal cycle of growth and decay of Ulva rigida Agardh in the Palude Della Rosa, lagoon of Venice. Estuarine Coast Shelf Sci 41:181-194

Vitiello P, Aissa P (1979) Observations sur la méiofaune d'une lagune sud-méditerranéenne. Rapp Comm Int Mer Médit 25/26: $137-138$

Warwick RM (1981) Survival strategies of meiofauna. In: Jones NV, Wolff WJ (eds) Feeding and survival strategies of estuarine organisms. Plenum Press, New York, pp 39-52

Warwick RM (1988) The level of taxonomic discrimination required to detect pollution effects on marine benthic communities. Mar Pollut Bull 19:259-268

Warwick RM, Clarke KR (1993) Increased variability as a symptom of stress in marine communities. J Exp Mar Biol Ecol $172: 215-226$

Warwick RM, Joint IR, Radford PJ (1979) Secondary production of the benthos in an estuarine environment. In: Jefferies RL, Davy AJ (eds) Ecological processes in coastal environments. Blackwell, London, pp 429-450

Warwick RM, Platt HM, Clarke KR, Agard J, Gobin J (1990) Analysis of macrobenthic and meiobenthic community structure in relation to pollution and disturbance in Hamilton harbour, Bermuda. J Exp Mar Biol Ecol 138:119-142

Watling L (1991) The sedimentary milieu and its consequences for resident organisms. Am Zool 31:789-796

Yentsch CS, Menzel DW (1963) A method for the determination of phytoplankton chlorophyll and phaeophytin by fluorescence. Deep-Sea Res 10:221-231

Zar JH (1996) Biostatistical analysis, 3rd edn. Prentice-Hall Inc., Englewood Cliffs, NJ 